\title{
Seroprevalence and risk factors of canine distemper virus in the pet and stray dogs in Haa, western Bhutan
}

Tshering Dorji ${ }^{1,2}$, Tenzin Tenzin ${ }^{3^{*}}$, Kuenga Tenzin ${ }^{4}$, Dawa Tshering ${ }^{3}$, Karma Rinzin ${ }^{5}$, Waraphon Phimpraphai ${ }^{1}$ and Michel de Garine-Wichatitsky ${ }^{1,6,7}$

\begin{abstract}
Background: Canine Distemper Virus (CDV) is a highly contagious virus belonging to family Paramyxovirade, genus Morbillivirus and responsible for high morbidity and mortality in dogs worldwide. Infected domestic dogs can cause spillover infections to wild carnivores that are in contact. We conducted a seroprevalence survey of CDV in domestic dogs in two areas of western Bhutan (Haa district) located at the periphery of the Jigme Khesar Strict Nature Reserve, which is home to several endangered wildlife. A total of 238 serum samples, 119 each from the pet and stray dog, were collected during summer and winter seasons. Samples were tested for CDV antibodies using a sandwich enzyme-linked immune-sorbent assay (ELISA) test.

Results: The seroprevalence of CDV was found to be $11.3 \%$ (95\% CI 6.7-14.2). Dogs sampled during winter were less likely to test seropositive against CDV antibodies than those sampled during summer (adjusted odds ratio: -2.6 ; 95\% Cl: - 1.2-6.1). Dogs in good body condition were found to be more likely to test seropositive against CDV than dogs in poor condition and obese dogs (adjusted odds ratio: 2.2; 95\% Cl: 0.1-5.9). There were no significant differences in the seroprevalence of CDV among different sexes, breeds and age classes, pet and stray dogs and between the two study sites.

Conclusions: Our study indicates that CDV seroprevalence was equally distributed among pet and stray dogs. We suggest strengthening the management practices of dogs through responsible dog ownership, dog population management and waste management to minimize the transmission risk of infectious diseases to wildlife.
\end{abstract}

Keywords: Free-roaming dog, Canine distemper virus, Protected area, Western Bhutan

\section{Background}

Canine Distemper Virus (CDV) belongs to a group of negative single-stranded and non-segmented RNA virus of species Canine Morbillivirus, genus Morbillivirus, family Paramyxovirade [1]. CDV is antigenically and genetically closely related to the other members of the morbillivirus genus, which includes measles virus,

\footnotetext{
* Correspondence: tenzinvp@gmail.com

${ }^{3}$ National Centre for Animal Health, Department of Livestock, Thimphu, Bhutan

Full list of author information is available at the end of the article
}

rinderpest virus and, peste des petits ruminant virus [2]. CDV is a highly contagious virus that can cause fatality in the domestic dog [3, 4]. The distemper virus affects a wide range of animal families, both domestic and wild, including Canidae (dog, fox, wolf, raccoon dog), Mustelidae (ferret, mink, skunk, wolverine, martin, badger, otter), Procyonidae (raccoon, coati), Ailuridae (red panda, giant panda), Ursidae (bear), Elephantidae (Asian elephant), some primates (Japanese monkey), Viverridae (civet), Pinnipedia (seals, walrus, sea lion), Felidae (large cats), Myrmecophagidae (Tamandua tetradactyla)

C C The Author(s). 2020 Open Access This article is licensed under a Creative Commons Attribution 4.0 International License, which permits use, sharing, adaptation, distribution and reproduction in any medium or format, as long as you give appropriate credit to the original author(s) and the source, provide a link to the Creative Commons licence, and indicate if changes were made. The images or other third party material in this article are included in the article's Creative Commons licence, unless indicated otherwise in a credit line to the material. If material is not included in the article's Creative Commons licence and your intended use is not permitted by statutory regulation or exceeds the permitted use, you will need to obtain permission directly from the copyright holder. To view a copy of this licence, visit http://creativecommons.org/licenses/by/4.0/ The Creative Commons Public Domain Dedication waiver (http://creativecommons.org/publicdomain/zero/1.0/) applies to the data made available in this article, unless otherwise stated in a credit line to the data. 
commonly known as Southern tamandua, and most recently reported in giant anteater (Myrmecophaga tridactyla) in Brazil [5-10].

Bhutan is considered as major biological hotspots due to the exceptional diversity and originality of its flora and fauna [11, 12]. Several vulnerable and endangered species are present in Bhutan, such as the common leopard (Panthera pardus), clouded leopard (Neofelis nebulosa), Snow Leopard (Panthera uncia) and Red Panda (Ailurus fulgens) [13-16]. These animals, may be directly threatened by infectious diseases such as CDV [5, 17-19]. The national conservation policies allow farmers to live within and adjacent to the protected areas in Bhutan, under specific rules regulating the use of natural resources and agriculture practices which presents both challenges and opportunities to conservation programs [20].

In Bhutan, Canine Distemper disease (CD) is common and there have been recurrent outbreaks in dogs resulting in mass mortality [21, 22]. Vaccination against CDV is done only in a limited number of pet dogs (individually owned) while the stray dogs are not vaccinated and thus remain susceptible to infection. A previous study in the Thimphu capital city indicated high seroprevalence (49.7\%) of CDV among dogs, but most positive cases were probably due to vaccination since the majority of pet dogs in Thimphu are vaccinated against the disease [23]. To our knowledge, no other studies have been conducted to determine CDV prevalence in dogs in other parts of Bhutan. The spillover infection of CDV from dogs to wild canids and felids is a potential threat for carnivore conservation $[3,17,18]$. Therefore, understanding the prevalence of CDV in free-roaming domestic dogs potentially in contact with susceptible wild carnivores in the periphery of the protected area is important to inform policies regarding dog population management and wildlife conservation. In this paper, we investigated the seroprevalence and the risk factors associated with CDV among pet and stray dogs in the Haa area, western Bhutan, located in the buffer zone of Jigme Khesar Strict Nature Reserve.

\section{Results}

\section{Dog demographic characteristics}

A total of 238 dogs were sampled, of which $51 \%$ were female in Esue rural geog and 49\% in Katsho semi-urban geog (sub-districts). Most of the dogs were local/non-descriptive breeds in Esue (90\%) and Katsho geog (69\%). The mean age of the dogs sampled from both areas was 3.25 year, with a minimum of 7 months and a maximum of 12 years. The distribution of dog age classes was similar between Esue and Katsho, although the age class [13-24 month] was overrepresented in Katsho and older dogs $(>49)$ were overrepresented in Esue $(t=2.8546$, $\mathrm{df}=27, P<0.01)$. The detailed characteristics of the sampled dogs are shown in Table 1.

Factors associated with seroprevalence of CDV in dogs Twenty-seven of the 238 dogs (11.3, 95\% CI: 6.7-14.2) were found to be seropositive to CDV. There was no significant difference in the prevalence of CDV between males and females, between pure/cross and local breeds, pet, and stray dogs, among different age categories, between neutered and entire dogs, and between the two study sites (Esue and Katsho). Only two variables, the season of sampling and body condition scores, were associated with CDV seropositivity. Dogs sampled during winter were less likely to test seropositive against CDV antibodies compared to those sampled during summer (adjusted odds ratio: -2.6 ; 95\% CI: - 1.2-6.1). Dogs with a body condition score of 5 (Obese), were more likely to test positive against CDV than other physical body condition (adjusted odds ratio: 2.2;95\% CI: $0.1-5.9$ ) (Table 2).

Table 1 Demographic characteristics of dogs sampled in Esue rural geog $(n=119)$ and Katsho semi-urban area $(n=119)$

\begin{tabular}{|c|c|c|c|}
\hline Variables & $\begin{array}{l}\text { Esue/rural } \\
\mathrm{n}(\%)\end{array}$ & $\begin{array}{l}\text { Katsho/semi-urban } \\
\mathrm{n}(\%)\end{array}$ & $\begin{array}{l}X^{2} \text { test } \\
\text { significance }\end{array}$ \\
\hline \multicolumn{4}{|l|}{ Sex } \\
\hline Female & $61(51)$ & $58(49)$ & \multirow[t]{2}{*}{0.79} \\
\hline Male & $58(49)$ & $61(51)$ & \\
\hline \multicolumn{4}{|l|}{ Breed $^{a}$} \\
\hline Pure/cross & $12(10)$ & $37(31)$ & \multirow[t]{2}{*}{0.0001} \\
\hline Local & $107(90)$ & $82(69)$ & \\
\hline \multicolumn{4}{|c|}{ Dog category/classification } \\
\hline Owned & $62(52)$ & $71(60)$ & \\
\hline Stray & $57(48)$ & $48(40)$ & 0.29 \\
\hline \multicolumn{4}{|l|}{ Age (months) } \\
\hline $4-12$ & $10(8.4)$ & $8(6.7)$ & \multirow[t]{4}{*}{0.008} \\
\hline $13-24$ & $11(9.2)$ & $19(16)$ & \\
\hline $25-48$ & $93(78.2)$ & $90(75.7)$ & \\
\hline$>49$ & $5(4.2)$ & $2(1.6)$ & \\
\hline \multicolumn{4}{|c|}{ Physical body condition score } \\
\hline 5-Obese & $10(8)$ & $18(15)$ & \multirow{5}{*}{0.28} \\
\hline 4-Fat & $72(60)$ & $57(48)$ & \\
\hline 3-Normal & $8(7)$ & $12(10)$ & \\
\hline 2-Thin & $15(13)$ & $17(14)$ & \\
\hline 1-Emaciated & $14(12)$ & $15(13)$ & \\
\hline \multicolumn{4}{|l|}{ Neuter status } \\
\hline Yes & $58(49)$ & $52(44)$ & \multirow[t]{2}{*}{0.51} \\
\hline No & $61(51)$ & $67(56)$ & \\
\hline
\end{tabular}

Note: ${ }^{a}$ Dog breed: Local means non-descript and mongrel dog; pure/cross mean pure breed (e.g. German Shepherd) and crosses between local and one identified pure breed 
Table 2 Final multivariable model of factors associated with seroprevalence of canine distemper virus in dogs sampled in Haa, Bhutan

\begin{tabular}{lllll}
\hline Variable & Coefficient & SE & $\boldsymbol{p}$-value & Odds Ratio $(95 \% \mathrm{Cl})$ \\
\hline Constant & & & \multicolumn{2}{l}{-} \\
& -1.60944 & 0.77460 & 0.037 & \\
Season & & & & \\
Summer & - & - & - & 1.00 \\
Winter & -19.76853 & 1533.91099 & 0.989 & $-2.6(-1.2-6.1)$ \\
Physical body condition score & & \\
Emaciated & - & - & - & 1.00 \\
Thin & -0.095 & 1.092 & 0.930 & $0.8(-1.6-2.9)$ \\
Average & 0.182 & 1.329 & 0.89 & $1.2(0.2-4.7)$ \\
Fat & 0.255 & 0.824 & 0.757 & $2.2(0.1-5.9)$ \\
Obese & 2.303 & & 0.028 & $1.9(0.2-6.6)$ \\
\hline
\end{tabular}

\section{Discussion}

Our study estimated the prevalence of CDV in both pet and stray dogs in rural and semi-urban communities of Haa district in Western Bhutan. The ELISA test used in this study only detected IgG antibodies. Thus, we could not differentiate between recent and past infections, and between vaccination and natural infections [24, 25]. However, since owners and livestock officials confirmed that the sampled dogs were not vaccinated against $C D$, we believe that the positive cases detected during our study are due to natural infections with CDV. Vaccination of dogs against $\mathrm{CD}$ remains expensive in most developing countries and it is logistically challenging to vaccinate stray and free-roaming dogs [26-28]. However, it is important to note that since the ELISA test is not $100 \%$ sensitive and specific, some samples could have been tested false positive or false negative and thus, this result should be interpreted cautiously.

The prevalence of CDV natural infection in highdensity domestic dog populations in our study area [29] emphasizes the risk of transmission among the domestic dog population, and of spillover infection to wild carnivores populations. In a previous study [30], we demonstrated that interactions between pet dogs and wildlife in an adjacent protected area of the study site were possible (Fig. 1). This is a concern for wildlife conservation as it poses significant transmission risks to several endangered wild canid and felid species, as observed in studies conducted elsewhere $[9,31,32]$. Farmers from the study site area reported observing frequent interactions between domestic dogs and wildlife, mostly at the periphery of agriculture land, and there is evidence of freeroaming dogs attacking Himalayan black bear in the study area [30].

Like any other infectious disease, the maintenance of $\mathrm{CDV}$ in a host population requires that the size of the susceptible population remains above the threshold. As wild carnivores occur at low densities, it is expected that the circulation of CDV is not maintained independently $[33,34]$. For instance, in Bhutan, the density of the tiger is estimated at 0.24 tigers per $100 \mathrm{~km}^{2}$ whereas the density of the snow leopard is estimated at 1.08 snow leopard per $100 \mathrm{~km}^{2}[35,36]$. However, despite their low densities; these two endangered species face significant risks of infection with CDV from domestic free-roaming dogs due to large stray dog populations at the periphery of protected areas, and occasionally inside, often resulting in dog-wildlife conflicts [37-39]. Additionally, the large density of free-roaming dogs in the country is considered as one of the major threats to Red panda conservation [40].

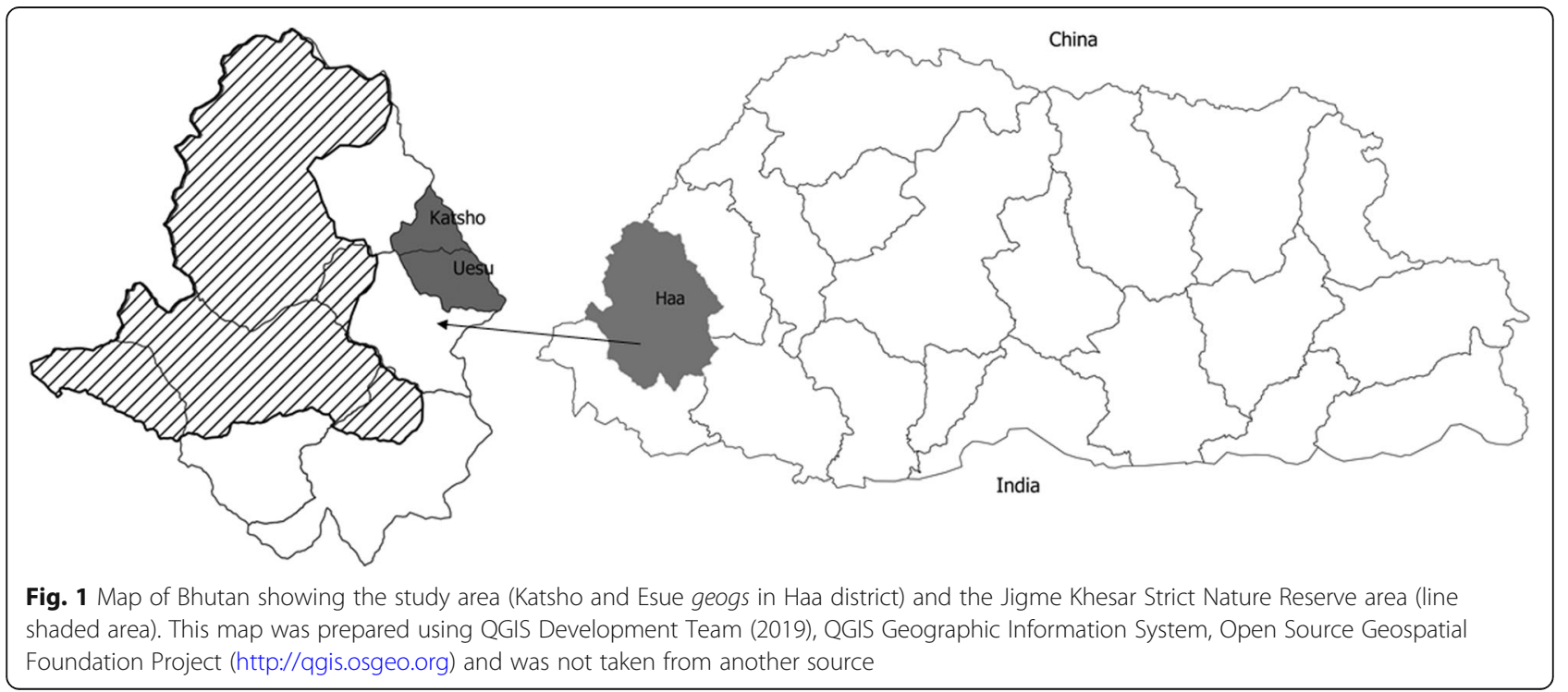


The current study findings of higher seropositivity to CDV during the summer season compared to winter may be associated with the probability of survival of CDV during warmer climatic conditions, as demonstrated in a similar study conducted elsewhere [41]. It has been documented that a sustained dog population management and pet ownership are the only solutions to reduce dog population, which would, in turn, reduce dog-wildlife interactions and resulting pathogen transmission [18, 34]. The sustained dog population management, through sterilization and waste management $[23,28,30]$, responsible pet ownership by providing proper food, shelters and health care services are some of the strategies that can reduce dog population in the country $[42,43]$. The government of Bhutan has placed high priority towards dog population and waste management and approved a special flagship program in the current plan. This is expected to have positive impacts by reducing the free-roaming dog population, improving animal welfare, reducing disease transmission (including CDV), thereby preventing spillover infection into wildlife [44-46]. In addition, vaccination of domestic freeroaming dogs against CDV may reduce disease transmission and benefit wildlife conservation as observed elsewhere [26, 41, 47].

\section{Conclusions}

Our serological study demonstrated that CDV circulates in domestic dog populations in the periphery of protected areas that hosts a range of endangered wildlife species potentially threatened by CDV. Since CDV is a highly infectious disease that can spill over to wildlife, particularly wild canids, we recommend that dog population control and management through responsible dog ownership, animal birth control program and waste management be carried out in areas where domestic dogs are likely to share habitat with wildlife. In addition, vaccination of both pet and stray dogs against CDV, within and outside protected areas where dog-wildlife interfaces occur, should be considered.

\section{Methods}

\section{Study area}

The study was conducted at the periphery of the Jigme Khesar Strict Nature Reserve (JKSNR), in Haa Dzongkhag (district), the western part of Bhutan (Fig. 1). This protected area was created in 1993 by the Royal Government of Bhutan. This is the only protected area without permanent human settlements, except for few migratory yak herds. A total of 29 species of mammals, 161 species of birds, 64 species of butterfly and seven species of fish have been recorded within this park boundary [48]. JKSNR is home to endangered species such as common leopard (Panthera pardus), Red Panda (Ailurus fulgens), Clouded leopard (Neofelis nebulosa), Snow Leopard (Panthera uncia), and Tiger (Panthera tigris) [35, 36, 49, 50], which are all listed as classified as vulnerable (VU) or endangered (EN) in the ICUN Red list of threaten species [14]. These species are vulnerable to CDV spillover infection from domestic free-roaming dogs, as has been experienced elsewhere $[9,18,19]$. This reserve area is also part of the transboundary conservation landscape - the Kangchenjunga landscape - that extends up to Sikkim in India and Nepal. There are six geogs (sub-districts) under Haa Dzongkhag, and we selected one semiurban geog (Katsho) and one adjacent rural geog (Esue), both located $6 \mathrm{~km}$ away from JKSNR boundary. The people in these geogs keep domestic animals and yaks that graze within the nature reserve area. Katsho geog is located at an altitude ranging from 2850 to $3100 \mathrm{~m}$ above sea level and has an area of 42.8 square meters. It is the smallest of the six geogs in Haa district which caters to 250 households and 1385 people. Esue geog has an area of $66.5 \mathrm{~km}^{2}$ and is located at an altitude of 2521 to 4076 masl. There are 11 villages with 255 households with a total population of 1907 [51].

\section{Sampling and laboratory analysis}

Using a priori CDV prevalence of 50\% [23] and with a $10 \%$ error and $95 \%$ confidence interval, a total of 238 serum samples were required to be collected from the two study sites. We collected two batches of serum samples: one batch in summer (August to September 2018) and one during winter (December 2018-February 2019). The samples were collected opportunistically during the Catch-Neuter-Vaccinate-Release campaigns (CNVR) of dogs conducted by the district livestock services of Haa during the summer season and through door-to-door visits for pet dogs during winter. Although there was no history of dog's vaccination against CDV in the study areas, only dogs that were above 4 months of age were included in the sampling to minimize the possible confounding influence of maternally derived antibodies. The age of pet dogs was collected through owner interview, whereas for stray dogs it was assessed by examining the dentition when under anesthesia for surgical operation during CNVR program. A minimum of $2 \mathrm{ml}$ of blood was collected from the cephalic vein and the serum samples were obtained following centrifugation. The samples were shipped to the National Centre for Animal Health laboratory in Thimphu and preserved at $-20^{\circ} \mathrm{C}$ until analysis. The samples were tested using a canine reactive ELISA kit as per the manufacturer instructions [24]. The other characteristics of the dogs such as sex, breed, body condition score and neutering status were collected at the time of sampling. 


\section{Data analysis}

Data were entered, cleaned and managed in Microsoft Excel (Microsoft Excel, Redmon, USA) and were analyzed in $\mathrm{R}$ statistical software (version 3.5) using the packages "dplyr","descr", "forcats", "lmtest", and "LogisticDx" [52]. The descriptive analysis was conducted by calculating the percentages and frequencies of the variables. The factors associated with seropositivity of the samples were assessed by performing logistic regression analysis. The associated factors investigated were age, sex, breed (local vs pure/cross) physical body condition score (obese, healthy, fair, weak and emaciated), sterilization status of the dog (yes vs no), category of dog (pet vs stray), the season of sample collection (summer vs winter) and sites of sampling (rural villages vs semiurban). Age of the dogs (continuous) were recategorized into four groups for regression analysis. Initially, a univariable logistic regression was performed with the sero-positive status of the dogs ( 1 or 0$)$ as an outcome and the above-mentioned factors as the predictor variables. The variables with a $p$-value of $<0.25$ were selected for the multivariable logistic regression model and those variables with $p<0.05$ were considered significant.

\section{Abbreviations}

CD: Canine distemper; CDV: Canine distemper virus; CNVR: Catch neuter vaccinate release; ELISA: Enzyme-linked immunosorbent assay;

IUCN: International Union for Conservation of Nature

\section{Acknowledgments}

The authors would like to thank all the dog owners for consenting to blood sample collection from their animals, and the staff of the livestock services based in Haa for providing their invaluable field support during this study.

\section{Authors' contributions}

TD, MdGW and WP conceptualized the study. TD conducted research under the supervision of MdGW, WP and TT. KR and TT provided scientific and administrative support to conduct field research. MdGW assisted with the conduct of the fieldwork during a 2 weeks mission in Bhutan. KT and TD collected the samples from the dogs and DT and TD conducted the ELISA test. TD, MdGW and TT conducted data analysis and drafted the manuscript. The authors (MdGW, TT, WP, KR, KT, DT) read and approved the final version.

\section{Funding}

The first author received a Fellowship from the International program, Bioveterinary Science of Kasetsart University (Thailand) to pursue the InterRisk Master's degree program. Kasetsart University (Thailand) and GREASE network supported the purchase of ELISA kit. The funding body had no role in the design of the study and collection, analysis, and interpretation of data and in writing the manuscript.

\section{Availability of data and materials}

All data generated or analysed during this study are included in the result section. The full datasets will be made available from the corresponding author on request.

\section{Ethics approval and consent to participate}

This study was approved by the Research Ethics Board, Department of Livestock, Ministry of Agriculture and Forests, Bhutan (vide letter No DoL/ Gen/RED/2017-18/056/Feb-11/18). A verbal consent was obtained from all participating dog owners and the CNVR program for blood sampling and data collection as approved by the ethics committee.
Consent for publication

Not applicable.

\section{Competing interests}

The authors declare no competing interests.

\section{Author details}

${ }^{1}$ Kasetsart University, Faculty of Veterinary Medicine, Bangkok, Thailand. ${ }^{2}$ District Veterinary Hospital, Department of Livestock, Gasa, Bhutan. ${ }^{3}$ National Centre for Animal Health, Department of Livestock, Thimphu, Bhutan.

${ }^{4}$ District Veterinary Hospital, Department of Livestock, Haa, Bhutan. ${ }^{5}$ Animal Health Division, Department of Livestock, Thimphu, Bhutan. ${ }^{6} \mathrm{CIRAD}$, UMR ASTRE, Montpellier, France. ${ }^{7}$ ASTRE, Univ Montpellier, CIRAD, INRA, Bangkok, Thailand.

Received: 4 December 2019 Accepted: 4 May 2020

Published online: 13 May 2020

\section{References}

1. Appel MJG, Gillespie JH, Siegert R. Canine distemper virus. In: Marburg virus. Vienna: Springer Vienna; 1972. p. 1-96. https://doi.org/10.1007/978-3-70918302-1_1.

2. Martinez-Gutierrez M, Ruiz-Saenz J. Diversity of susceptible hosts in canine distemper virus infection: a systematic review and data synthesis. BMC Vet Res. 2016:12(1). https://doi.org/10.1186/s12917-016-0702.

3. Norris JM, Krockenberger MB, Baird AA, Knudsen G. Canine distemper: reemergence of an old enemy. Aust Vet. 2006;84(10):362-3. https://doi.org/10. 1111/j.1751-0813.2006.00032.

4. Feng $N$, Yu Y, Wang T, Wilker $P$, Wang J, Li Y, et al. Fatal canine distemper virus infection of giant pandas in China. 2016;6(1):1-7. https://doi.org/10. 1038/srep27518

5. Alexander KA, Appel MJG. African wild dogs (Lycaon pictus) endangered by a canine distemper epizootic among domestic dogs near the Masai Mara National Reserve, Kenya. J Wildl Dis. 1994;30(4):481-5. https://doi.org/10. 7589/0090-3558-30.4.481

6. Woodroffe R, Donnelly CA. Risk of contact between endangered African wild dogs Lycaon pictus and domestic dogs: opportunities for pathogen transmission. J Appl Ecol. 2011;48(6):1345-54. https://doi.org/10.1111/j.13652664.2011.02059.

7. Lunardi M, Darold GM, Amude AM, Headly SA, Sonne L, Yamuuchi KCl, et al. Canine distemper virus active infection in order Pilosa, family Myrmecophagidae, species Tamandua tetradactyla. Vet Microbiol. 2018;220: 7-11. https://doi.org/10.1016/j.vetmic.2018.04.030.

8. Gowtage-Sequeira S, Banyard AC, Barrett T, Buczkowski H, Funk SM. Cleaveland $\mathrm{S}$ epidemiology, pathology, and genetic analysis of a canine distemper epidemic in Namibia. J Wildl Dis. 2009;45(4):1008-20. https://doi. org/10.7589/0090-3558-45.4.1008.

9. Jin Y, Zhang X, Ma Y, QiaoY LX, Zhao K, et al. Canine distemper viral infection threatens the giant panda population in China. Oncotarget. 2017; 8(69):113910-9. https://doi.org/10.18632/oncotarget.23042.

10. Granjeiro MDB, Kavasaki ML, Morgado TO, Pavelegini LAD, de Barros MA, Fontana $\mathrm{C}$, et al. First report of a canine morbillivirus infection in a giant anteater (Myrmecophaga tridactyla) in Brazil. Vet Med Sci. 2020:1-6. https:// doi.org/10.1002/vms3.246.

11. Gillison AN. Biodiversity in Bhutan: a preliminary synthesis; 2012. p. 164. Available from. http://biodiversity.bt/biodiv/content/documents/documentf4cfe3a2-b846-4cf8-bd98-24d622951046/647.pdf.

12. Banerjee A, Bandopadhyay R. Biodiversity hotspot of Bhutan and its sustainability. Curr Sci. 2016;110(4):521. https://doi.org/10.18520/cs/v110/i4/ 521-528.

13. Kamler JF, Songsasen N, Jenks K, Srivathsa A, Sheng L, Kunkel K. IUCN, Cuon alpinus: the IUCN red list of threatened species. Int Union Conserv Nature. 2015. https://doi.org/10.2305/IUCN.UK.2015-4.RLTS.T5953A72477893.en.

14. Mallon DP, Jackson RM. A downlist is not a demotion: red list status and reality. Oryx. 2017;51(4):605-9. https://doi.org/10.1017/S0030605317000606.

15. IUCN Red List India. Red data list, red book Part-1, PMF IAS; 2019. Available from. https://www.pmfias.com/iucn-red-list-india-red-data-list-red-book.

16. Simms A, Moheb Z, Salahudin AH, Ali I, Wood T. Saving threatened species in Afghanistan: snow leopards in the Wakhan corridor. Int J Environ Stud. 2011;68(30):299-312. https://doi.org/10.1080/00207233.2011.577147. 
17. Vanak AT, Belsare AV, Gompper ME. Survey of disease prevalence in freeranging domestic dogs and possible spill-over risk for wildlife - a case study from the great Indian bustard sanctuary, Maharashtra - IndiaFinal report submitted to the Rufford Small Grants Foundation, UK; 2007. p. 1-13.

18. Acosta-Jamett G, Chalmers WSK, Cunningham AA, Cleaveland S, Handel IG, Bronsvoort BMD. Urban domestic dog populations as a source of canine distemper virus for wild carnivores in the Coquimbo region of Chile. Vet Microbiol. 2011. https://doi.org/10.1016/j.vetmic.2011.05.008.

19. Gilbert M, Soutyrina SV, Seryodkin IV, Sulikhan N, Uphyrkina OV, Goncharuk M, et al. Canine distemper virus as a threat to wild tigers in Russia and across their range. Integr Zool. 2015;10(4):329-43. https://doi.org/10.1111/1749-4877.12137.

20. Wang SW, Lassoie JP, Curtis PD. Farmer attitudes towards conservation in Jigme Singye Wangchuck National Park, Bhutan. Environ Conserv. 2006; 33(2):148-56. https://doi.org/10.1017/S0376892906002931.

21. Kuensel. Phuentsholing reports cases of canine distemper. Available from: https://kuenselonline.com/phuentsholing-reports-cases-of-caninedistemper/. Accessed 25 Nov 2019

22. Bhutan Broadcasting Services (BBS). Canine Distemper Virus outbreak subsiding. Available from. http://www.bbs.bt/news/?p=122547. Accessed 20 Oct 2019.

23. Rinzin K. Population dynamics and health status of free-roaming dogs in Bhutan, PhD Thesis 2015, Murdoch University, Australia.

24. Abbexa. Dog canine distemper virus (CDV) ELISA kit- product manual. Catalog no.: abx055327; 2017.

25. Costa VGD, Saivish MV, Rodrigues RL, Silva RFD, Moreli ML, Krüger RH. Molecular and serological surveys of canine distemper virus: a meta-analysis of cross-sectional studies. PLoS One. 2019;14(5). https://doi.org/10.1371/ journal.pone.0217594.

26. Flores-Ibarra M, Estrella-Valenzuela G. Canine ecology and socioeconomic factors associated with dogs unvaccinated against rabies in a Mexican city across the US-Mexico border. Prev Vet Med. 2004;62(2):79-87. https://doi. org/10.1016/j.prevetmed.2003.10.002.

27. Dalla-Villa P, Kahn S, Stuardo I, lannetti I, Nardo AD, Serpell JA. Free-roaming dog control among OIE-member countries. Prev Vet Med. 2010;97(1):58-63. https://doi.org/10.1016/j.prevetmed.2010.07.001.

28. Slater MR. Understanding issues and solutions for unowned, free-roaming cat populations. J Am Vet Med Assoc. 2004;225(9):1350-4. https://doi.org/10. 2460/javma.2004.225.1350.1.

29. Rinzin K, Tenzin T, Robertson I. Size and demography pattern of the domestic dog population in Bhutan: implications for dog population management and disease control. Prev Vet Med. 2016;126:39-47. https:// doi.org/10.1016/.jprevetmed.2016.01.030.

30. Dorji T, Tenzin T, Rinzin K, Phimpraphai W, de Garine-Wichatitsky M. Community perceptions of free-roaming dogs and management practices in villages at the periphery of a protected area in Bhutan. CMU J Nat Sci. 2020;19(2) Available from. http://cmuj.cmu.ac.th/cmu_journal/in_press.php.

31. Cleaveland S, Mlengeya T, Kaare M, Haydon D, Lembo T, Laurenson MK, et al. The conservation relevance of epidemiological research into carnivore viral diseases in the Serengeti. Conserv Biol. 2007;21(3):612-22. https://doi. org/10.1111/j.1523-1739.2007.00701.

32. Acosta-Jamett G, Surotb D, Cortésa M, Marambioa V, Valenzuelaa C, Vallverdua A, et al. Epidemiology of canine distemper and canine parvovirus in domestic dogs in urban and rural areas of the Araucanía region in Chile. Vet Microbiol. 2015;178(3):260-4. https:/doi.org/10.1016/j.vetmic.2015.05.012.

33. Deem SL, Yates RA. Canine distemper in terrestrial carnivores: a review. J Zoo Wildl Med. 2001;31(4):441-51.

34. Gog J, Woodroffe R, Swinton J. Disease in endangered metapopulations: the importance of alternative hosts. Proc R Soc Lond B Biol Sci. 2002; 269(1492):671-6.

35. Lham D, Wangchuck U, Wangchuk, Wangchuk N, Lham K, Namgay T, et al. National snow leopard survey of Bhutan 2014-2016 [phase II]: camera trap survey for population estimation; 2016. Available from. http://www. bhutantrustfund.bt/wp-content/uploads/2018/11/National-Snow-LeopardSurvey-of-Bhutan-2014-2016-Phase-II-Camera-Trap-Survey-for-PopulationEstimation-DoFPS.pdf.

36. Tempa T, Mark H, Jousha FG, Norbu N, Tshewang RW, Wenhong X, et al. The spatial distribution and population density of tigers in mountainous terrain of Bhutan. Biol Conserv. 2019;238:108-92. https://doi.org/10.1016/j. biocon.2019.07.037.

37. Kuensel. Haa to consult people on imposing fine to control stray dog population. Availabel from. https://kuenselonline.com/haa-to-consult- people-on-imposing-fine-to-control-stray-dog-population/. Accessed 15 Aug 2019.

38. Bhutan Broadcasting Services. Stray dogs cause nuisance in Haa. Bhutan Broadcasting Services. Available from. http://www.bbs.bt/news/?p=27425.

39. Bhutan Today. When the wild comes to town-displacement of wild animal by stray dogs highest. Available from. http://www.bhutantoday.com.bt/ when-the-wild-comes-to-town/. Accessed 20 Aug 2019.

40. Dorji $\mathrm{S}$, Vernes K, Rajaratnam R. Habitat correlates of the red panda in the temperate forests of Bhutan. PLoS One. 2011;6(10):26483. https://doi.org/10. 1371/journal.pone.0026483.

41. Böhm M, Herrtage ME, Thompson H, Weir A, Hasted AM, Maxwell NS. Serum antibody titers to canine parvovirus, adenovirus and distemper virus in dogs in the UK which had not been vaccinated for at least three years. Vet Rec. 2004;154(15):457-63. https://doi.org/10.1136/vr.154.15.457.

42. Gunaseelan S, Coleman GJ, Toukhsati SR. Attitudes toward responsible pet ownership behaviors in Singaporean cat owners. Anthrozoös. 2013;26(2): 199-211. https://doi.org/10.2752/175303713X13636846944123.

43. Rohlf VI, Bennett PC, Toukhsati S, Coleman G. Why do even committed dog owners fail to comply with some responsible ownership practices. Anthrozoös. 2010;3(2):143-55. https://doi.org/10.2752/ $175303710 \times 12682332909972$

44. Ministry of Agriculture and Forests Bhutan. National Dog Population Management Strategy launched. Available from. http://www.moaf.gov.bt/ national-dog-population-management-strategy-launched/. Accessed 30 Apr 2019.

45. Kuensel. Stray dog population to be addressed with waste management. Available from. https://kuenselonline.com/stray-dog-problem-to-beaddressed-with-waste-management/. Accessed 16 Dec 2019.

46. Kuensel. Engaging residents to curb dog population. Available from. https:// kuenselonline.com/engaging-residents-to-curb-dog-population/. Accessed 20 Jan 2019.

47. Belsare AV, Gompper ME. Assessing demographic and epidemiologic parameters of rural dog populations in India during mass vaccination campaigns. Prev Vet Med. 2013;11(1-2):39-146. https://doi.org/10.1016/j. prevetmed.2013.04.003.

48. Namgay P. Jigme Khesar strict nature Reserve-Department of Forest \& park services. Available from. http://www.dofps.gov.bt/?page_id=234. Accessed 1 Dec 2019

49. Dorji S, Vernes $K$. The vulnerable red panda Ailurus fulgens in Bhutan: distribution, conservation status and management recommendations. Oryx. 2012;46:536-43. https://doi.org/10.1017/S0030605311000780.

50. Penjor U. The conservation of clouded leopard Neofelis nebulosa (Griffith, 1821) in Bhutan; 2018. Available from http://bes.org.bt/wp-content/ uploads/2018/02/Proceedings-of-BES_2015_2.4The-Conservation-of-cloudedleopard-Neofelis-nebulosa-Griffith-1821-in-Bhutan-pdf.

51. National Statistical Bureau (NSB). Population and housing census, Bhutan, PHCB Haa dzongkhag; 2017. Available from. http://www.nsb.gov.bt/ publication/files/PHCB2017_national.pdf.

52. Team, R. Core. R: a language and environment for statistical computing. Vienna: R Foundation for Statistical Computing; 2017. ISBN3-900051-07-0. Available from https://www.R-project.org.

\section{Publisher's Note}

Springer Nature remains neutral with regard to jurisdictional claims in published maps and institutional affiliations.

Ready to submit your research? Choose BMC and benefit from:

- fast, convenient online submission

- thorough peer review by experienced researchers in your field

- rapid publication on acceptance

- support for research data, including large and complex data types

- gold Open Access which fosters wider collaboration and increased citations

- maximum visibility for your research: over $100 \mathrm{M}$ website views per year

At BMC, research is always in progress.

Learn more biomedcentral.com/submission 